\title{
Def Poetry's Public: Spoken Word Poetry and the Racial Politics of Going Mainstream
}

\author{
Susan B.A. Somers-Willett
}

It's imperative that these spoken word artists be catapulted to the mainstream and be recognized. Finally the marriage between hip-hop and spoken word can begin the arduous task of reconciliation.

- Bruce George, former Executive Producer of Russell Simmons Presents Def Poetry

Rap has been raped by marketing. Spoken word is still pure. It is up to the poets to keep it that way.

-Flowmentalz, spoken word poet featured on Russell Simmons Presents Def Poetry

American poetry is currently enjoying a renaissance in the public sphere. Whereas less than twenty years ago poetry was declared "dead" to the public because it was largely practiced within the academy, poetry events can now command mainstream and even commercial audiences, particularly among US youth. ${ }^{1}$ This popularity has been achieved in great part through performances of poetry in public venues, including those of readings, recitations, and poetry slams. Another example can be

Susan B.A. Somers-Willett is a poet, performer, and scholar who has competed and coached at a number of National Poetry Slams. She is the author of a collection of poetry, Roam (Crab Orchard Award Series, 2006), and is the recipient of a Mellon Postdoctoral Fellowship from the University of Illinois at Urbana-Champaign. She is currently a visiting scholar at the Center for the Arts in Society at Carnegie Mellon University, where she is researching the impact of public poetry projects on American culture. 
found in the emerging commercial genre of spoken word poetry. Although a wide variety of verse - from Beat poetry to the warbled musings of William Shatnerfalls under spoken word's purview, in contemporary parlance the term most often denotes urban street lyrics using the jazz or hip-hop idiom. In its connection with African American music and culture, spoken word poetry has achieved a new sense of materiality, proving through various media projects both popular and profitable.

Such is the case with the HBO television series Russell Simmons Presents Def Poetry and its theatrical incarnation, Def Poetry Jam, performed at San Francisco's Theater on the Square in 2002 and at Broadway's Longacre Theater in 2002 and 2003. In claiming to deliver a more authentic form of lyrical expression, the Def Poetry projects focus on images of urban blackness and the ties of spoken word poetry to black popular music. These projects may be intended for and indeed may reach a racially diverse audience, but nevertheless they are primarily consumed by white mainstream culture. As such, the Def Poetry projects pose a number of questions about racial identity, materiality, and the politics of consumption behind this kind of verse. Perhaps the most urgent of these questions are: In what ways are black poets made marketable in the commercial arena of spoken word, and what desires might their mainstream, cross-racial consumption engender? To answer these questions, I consider the poets, poems, and marketing strategies of the Def Poetry empire from the perspectives of both verse and culture.

The issue of representation is vexed for African American spoken word poets, as it is for most black artists operating in mainstream commercial venues. As "representatives," African American poets operating in these venues may be and often are received as embodying the illusion of racial authenticity surrounding black speech, gestures, situations, or themes which can ultimately be limiting for both the artist and the work. Still, media projects claiming to represent African American voices and culture engage a larger political method of cultural redress. Because African Americans have been excluded from many mainstream media outlets in the past, makers of these projects argue that black artists should be featured prominently or even exclusively, as the philosophy "for us, by us" - a trademark of the popular black clothing line FUBU - suggests. In such venues, the political imperatives of racial representation can supercede issues of poetic quality or artistic merit. Such is the case with Def Poetry in its mission to represent an urban ethnic demographic. One poet reported being told during an HBO Def Poetry series taping that poets would be selected to appear in the final version of the show first on the basis of ethnicity, secondly on gender, and only thirdly on the quality of their poetry.

The two epigraphs of this essay shed light on why this bias exists. Bruce George represents the marketer's point-of-view, suggesting that making a link between hiphop and spoken word poetry is a positive step and will help the latter achieve mainstream commercial success. Flowmentalz, on the other hand, reflects the widespread opinion among spoken word poets that commercial attention will prove negative for the art form. He suggests most hip-hop is created with commercial interests in mind, while spoken word poetry remains untouched by such interests and is therefore a more authentic mode of lyrical expression. Both opinions, although they seem to directly compete with each other, are essential to spoken 
word's mainstream commercial success. Indeed, it is precisely this tension that enhances the spoken word artist's current cachet with mainstream audiences. Displaying mastery of the rapper's idiom while critiquing the rapper's hackneyed and materialistic public image, the spoken word poet lays claim not only to lyrical authenticity, but to racial authenticity - a highly valuable commodity in today's mainstream youth markets.

As an umbrella term, performance poetry can encompass a number of different types of verse in performance: slam poetry, avant-garde performance poetry, hiphop, song lyrics, and even the libretto. I use the term "spoken word poetry" here to denote such a subset of performance poetry, one which has commercial purposes and strong associations with popular audio and visual media. Audiences are almost exclusively using the term to indicate a hip-hop infused lyric, and in many cases spoken word poetry is indistinguishable from hip-hop itself, save its attention to political message. This association is, no doubt, heavily influenced by those in the recording industry who are actively working to link one very lucrative recording category (hip-hop) to another with relatively untapped commercial potential. Use of the term "spoken word" came about in the early twentieth century as a way to refer to the recorded, performed text of broadcast radio as opposed to written journalism and radio plays. When The National Academy of Recording Arts and Sciences established the Grammy Awards in 1958 for excellence in recording, they recognized this category officially by creating a Best Documentary or Spoken Word Performance award (Grammy Awards). Over the years, the types of recordings recognized in this category have expanded to include a number of different types of recited and performed work, but what is most important to acknowledge here is that the term spoken word has, unbeknownst to many of its practitioners and consumers, commercial origins. As it exists today in its more specific but nonetheless commercial incarnation, spoken word poetry is positioned at the nexus of hip-hop music and slam poetry, and as such proves a well-lit stage upon which the tension between commercial and artistic interests plays out through the lyric.

The wave of media interest in spoken word poetry during the last decade seems linked to the success of gangsta rap (also known as hardcore or thug rap) with young white suburban audiences in the early 1990s. This sub-genre of hip-hopwhich celebrated black criminality, promiscuity, misogyny, drug use, and ghetto violence - capitalized upon a social climate in America in which black-white racial tensions ran high, projecting an urban black male criminality that white audiences seemed to both fear and revere. Gangsta rap's anti-white sentiment only broadened its appeal to young suburban white males because of its outspoken resistance to dominant culture, and this sentiment became one of its crucial selling points to popular audiences. Rap music as a whole, as New Republic critic David Samuels suggests, followed the fashion of its subjects and styles, becoming more "closed" to white audiences. Furthermore, hip-hop labels took care to increase the marketability of rappers by advertising their street credentials. In more than one instance, this was achieved by peppering rappers' mainstream PR campaigns with details about their criminal records (27). In the 1990s, it was no secret among recording executives and artists that the more racially exclusive rap presented itself to be, the more "authentic" and hence desirable the thug sound and image became to white 
suburban audiences. The popularity of the gangsta image across race and class divides led to the production (and then overproduction) of albums and films about black urban culture during this period. The superabundance of the thug image spurred S. Craig Watkins to ask in 1998: "Is there any life in black popularculture after ghettocentricity? In other words, as the gangsta motif loses its commercial viability, what is on the immediate horizon for black cultural and representational politics?" (237).

Exactly at that time, a new crossover image surfaced in mainstream U.S. media, one with its own pros and cons: the black spoken word poet. Although it is distinct from and often challenges the rapper's lifestyle and attitudes, the image of the black spoken word poet grows out of, and thereby is often iterated in reference to, the hardcore rapper's image. To be clear, much of what spoken word poetry does in commercial venues is point out the foibles and falsehoods of the gangsta's lifestyle, and in this respect the two images would appear to rest at opposite ends of the spectrum. However, part of what lends the image of the black spoken word poet his authenticity is that he is fluid in the hip-hop idiom (i.e., he can flow). ${ }^{2}$ Spoken word poet Jerry Quickley remarks,

To actually represent hip-hop flavor and styles within poetry, you must be able to represent, or rap, straight hip-hop. If you effectively manifest hip-hop poetry styles, it means that you have the ability to use both straight up hip-hop and straight up poetry (free verse, haiku, sonnets, whatever). Being a poet using hiphop styles does not mean that you throw in some timely ghetto colloquialism and vaguely clever but ultimately overtly self-conscious end-rhymes. It means that you can choose to bend your styles to your will both within your written work and within your performances, all the while keeping your uniqueness and tone intact. There are artists who claim to represent hip-hop poetry, and if they were ever caught in a cipher (a group of MCs flowing verse) they would be like the proverbial deer caught in a beat box's headlights. (41-2)

Quickley emphasizes the virtuosity required for a spoken word poet operating in the hip-hop idiom to be considered authentic. Indeed, one appeal to white middleclass audiences of a black spoken word poet reflecting hip-hop styles may be that he chooses to express himself using the language of hip-hop but within the venue of spoken word poetry, where braggadocio about sexual conquest, drugs, and ghetto violence are not only discouraged but — as I will discuss in a moment - critiqued in a play for cultural authenticity. In this respect, as commercial media portrays him (and it bears mention that the image is most often male), the black spoken word artist is often presented as the rapper reformed through poetic expression. In such cases, spoken word poetry helps put a kinder, gentler face on those practicing in the hip-hop idiom; while its content reflects a more enlightened view, its lyrical tools are still those culturally closed (and hence racially authentic) stylings of the rapper.

This authenticity ascribed to black voices and narratives can signal not only fetishization on behalf of white bourgeois audiences, but also commodification. Gareth Griffiths argues, "authentic speech, where it is conceived not as political 
strategy but as a fetishized cultural commodity, may be employed ... to enact a discourse of 'liberal violence,' re-enacting its own oppressions on the subjects it purports to represent and defend" (241). The media industry has taken note of the popularity of spoken word poetry with young consumers, inspiring a number of corporate campaigns (such as those of Perry Ellis, Red Bull, ESPN, MTV, and Nike) which exhibit this type of liberal violence. Most recently, McDonald's jumped on the spoken word bandwagon with an advertising campaign featuring an African American woman waxing poetic about salads in what the company's director of marketing described as the "def poetry" mode (Jefferson). Surveying the range of spoken word poetry video and audio recordings which are not self-produced and which strive to find mainstream audiences, one will find that most performers represented are of color and that the majority are African American. This trend seems to indicate that, like some brands of rap, commercial interests in performance poetry are invested in capitalizing upon the authenticity of black urbanity and its popularity with white middle-class suburban youth. The ghettocentricity of many such spoken word projects shows how poverty and urbanity can easily become characteristic components of so-called authentic black culture when set in a commercial context. Gender can also serve as such a characteristic component; many mainstream spoken word projects, like some in hip-hop, rely upon narratives of black urban masculinity as signals of their authenticity or "realness." With the idea of liberal violence in mind, issues of audience, perceptions of racial authenticity, and the politics of consumption come acutely into relief.

\section{"Dropping Truth": Def Poetry's Marketing of Spoken Word to the Mainstream}

The first of the Def Poetry projects was the HBO series Russell Simmons Presents Def Poetry. Soon after the series debuted in 2001, poets from the show appeared at U.S. colleges and universities as part of a Def Poetry tour, reading their work in live performances with celebrity MCs such as Chuck D from the rap group Public Enemy. At the same time, other poets performed in a stage version of Def Poetry in San Francisco, a show which eventually made its way to New York City's Broadway circuit in November of 2002. The cable series, which won a Peabody Award in 2003, aired its fifth season on HBO in the summer of 2006. The program is advertised on that network as one of its hottest original series alongside the cable blockbusters The Sopranos, Deadwood, Entourage, and Six Feet Under.

Russell Simmons, figurehead of the Def Poetry productions, is a hip-hop recording mogul whose roster of accomplishments includes managing the rap group RunDMC in the early 1980s, co-founding the Def Jam recording label in 1984, producing the HBO series Def Comedy Jam in 1991, and founding the Phat Farm hip-hop clothing line in 1992. His career has been characterized by marrying business interests with black hip-hop culture; a recent Business Week cover story hailed Simmons with the title "The CEO of Hip-Hop" (Berfield). Ever-dedicated to the African American community, his business interests have recently been supplemented with political activism among black urban youth. In 2001, Simmons founded the Hip-Hop Summit Action Network - which sponsors voter initiatives, educational reform, and community programs targeting the hip-hop generation-with former NAACP 
Executive Director Benjamin F. Chavis (93). Still, Simmons remains a shrewd entrepreneur and has succeeded in building an empire of businesses that center around, if not help to define, hip-hop culture. These projects are all reflective of "his desire for the 'hip-hopification' of American media" ("Who's Who").

Simmons' projects are known not only for promoting black artists to black audiences, but also for attracting "crossover" white audiences; Run-DMC, for example, is generally recognized as the first rap group to attract such an audience and to be featured by mainstream media sources such as Rolling Stone and MTV (Watkins 179, 272). Similarly, DefComedy Jam introduced white and black audiences alike to a new cadre of black comedians including Bernie Mac, Cedric the Entertainer, Martin Lawrence, Jamie Foxx, and Chris Rock by exercising the "for us, by us" philosophy. As much as these stand-up performances may have been intended for (and indeed taped in front of) predominately black audiences, it appears, as Samuels suggests of rap, that even the most racially-exclusive forms of entertainment can prove popular among white mainstream audiences, in part because they are racially exclusive and lend Def Jam projects an air of insiderism (and hence authenticity). For these artists, as it has been for many black performers, going mainstream and earning a commercial presence has usually meant gaining an audience among white suburban youth.

Def Poetry has won this market share by contextualizing spoken word poetry within traditionally black hip-hop culture and aggressively marketing this angle. The majority of the cable show's featured artists are African American, and many of its artists reflect hip-hop aesthetics in their work by employing rhythmically rhymed language, urban subject matter, and hip-hop slang. The featured poets are also predominately male; to date, roughly two-thirds of the performers appearing on the HBO series are male, and of the African American performers, about three-quarters are male. The show takes much of its on-screen flavor from its MC Mos Def, a famous Brooklyn-based rapper and actor. Between acts, a DJ spins hip-hop tracks, and Mos Def sometimes performs a call-and-response ritual at the beginning of the show ("Where Harlem at? Where Queens at? Brooklyn, stand up!"). The choice to have a readily recognizable hip-hop artist host the show is a deliberate gesture toward bringing hip-hop audiences to spoken word poetry, and Mos Def's freestyle rapping before or after each episode further emphasizes a connection between the two. Simmons' perfunctory appearance at the end of each episode (in which he usually embraces Mos Def, states to the audience, "I hope you were inspired. God Bless," and quickly exits) seals the connection between the hip-hop and spoken word poetry worlds and helps to lend the show commercial legitimacy. All of these elements work to target the mainstream audience for hip-hop albums - mostly white middle-class suburban youth - as the audience for spoken word poetry.

To compound the show's crossover appeal, the HBO series features famous recording stars (such as Jewel, Erykah Badu, Wyclef Jean, Kanye West, and The Last Poets), "icon" poets of literary note (including Sonia Sanchez, Nikki Giovanni, Amiri Baraka, Sharon Olds, and Haki Madhubuti), and celebrities (such as Malcolm Jamal Warner, Dave Chappelle, and Benjamin Bratt) alongside the poets. Many of the poets featured on the Def Poetry series are politically outspoken and perform 
work about their identities. Most of the poets featured are also from large urban areas such as New York, Atlanta, Chicago, and Los Angeles, and the subjects of poverty, crime, imprisonment, racism, and violence are commonly addressed.

The series has also featured comedians from the Def Comedy Jam stage, including Jamie Foxx and Cedric the Entertainer, performing routines which parody other images of the black poet circulating in mainstream culture, in turn legitimating - if not authenticating - the "def" spoken word poet. Jamie Foxx performed a character sketch on the show, dressing in Afrocentric garb and comically waving a stick of incense. He performed a poem entitled "Off the Hizzle for Shizzle" (Off the Hook for Sure), in which he has a one-night stand with a woman who steals his money and gives him a venereal disease. The performance is a rhymed parody of two common images of the spoken word artist in black culture: the Afrocentric poet and the rapper bragging about his latest sexual conquest. His dress and wild gesticulations with the incense reflect his critique of the former; his abundant use of "izzle" pig Latin to rhyme reflects his parody of the latter. ${ }^{3}$ Cedric the Entertainer's performance is similarly critical of the Afrocentric poet's image:

So I'm inside this coffeehouse, 'coz I want one of those caramel frappachino things, when I was informed that it's poetry night. Lights dim, candles are burning, African drums beat [laughter] ... It's just about that time that I start to think to myself, even pray, "Oh Lord, please don't let this be another cliché" [laughter]. You know - the dreadlock hair and Erykah Badu music, soulchild, headwrap-wearing brother that talks like this [laughter as he gives an exaggerated emphasis to his words] and gonna tell me way too much about his childhood, or how the white man keep keepin' tha brotha down [laughter], or use the word molasses in so many forms that I don't even wanna put syrup on my damn pancakes [intense laughter]. I'm just sayin', you see, sometimes for the layman - and in this case I claim to be-spoken word, or poetry as it's known in this more pop cultural form, can be just one meteoric metaphor too much [laughter], two dangling participles too long [laughter], and just flat-out too damn deep [intense laughter]. But don't sleep; I want you all to peep, this. (Russell Simmons Presents)

As he continues the rest of his monologue in semi-regular rhyme, Cedric contrasts this "clichéd" work to that of the spoken word artists appearing on Def Poetry, poets who "send you on cerebral vacations and mind excavations" and demonstrate that "words are often the tools that separate us from the fools." He concludes by endorsing the poetry as it appears on the Def Poetry series: "To the spoken word artist, I give you your props, your kudos, and your standing Os. 'Coz not only are you the hot butter with the toast, but you now have your own jam." Notably, Cedric employs rhyme only when delivering his encomium for the spoken word artist, formally marking the break from his comedic monologue to lyrical expression and his temporary shift from "def comic" to "def poet" on the HBO stage.

Cedric and Foxx's performances illustrate that even though the HBO series places spoken word poetry within a highly commodified vision of black urban culture, Def 
Poetry performances such as these can be, as Tricia Rose notes of hip-hop, "a public and highly accessible place where black meanings and perspectives - even as they are manipulated by corporate concerns - can be shared and validated among black people" (Rose 17). These meanings are, I would add, intimately connected with the intercultural and multiracial exchanges that take place in mainstream venues such as the Def Poetry series. Even if Def Poetry is intended for black audiences, airwaves themselves do not discriminate in their viewership (except, of course, if one cannot afford the subscription fee for the cable network). When white audiences tune in to watch a show so focused on representing African American poets and culture, what happens? In these moments that could be most accurately described as "cultural eavesdropping," the meaning of blackness itself is negotiated and exchanged between and across race and class spectrums.

Poets have used the Def Poetry stage to critique hip-hop culture itself, offering an image of the spoken word poet as more virtuosic and hence authentic than the rapper. For example, in one episode, National Poetry Slam Champion Sekou tha Misfit performs a parody of the now hackneyed rapper's braggadocio entitled "The Rapper." In the persona of a hardcore thug, he details the wealth, sexual conquests, and the adulating company that rap-star status affords his character while revealing the emptiness of each aspect of this lifestyle. Throughout the body of the poem, the rapper's rhetoric is revealed as false: although high-rolling he sheepishly admits to the audience, "I'm broke;" although a pimp he admits, "I respect women;" although bragging about using automatic weapons, he admits, "I don't own a gun." Speaking first in the rapper's voice and then in his own voice as a spoken word poet, Sekou concludes:

Of all ya'll hard thugs I'm the hardest

Leave your ass dearly departed, or severely retarded

I'll kill your wife, I'll kill your dog, I'll kill your turtle

I'll kill your kids, I'll kill your kids' future kids

Then spit some cliché bullsh-t like:

"That's just how it is..."

I'm hard - hard as the eyes of killer, hard as the hands of a slave,

I've never known love, and never been afraid,

I'm hard as a body that's dead, hard as a convict's bed,

Hard as my d--ck when I'm getting head - but the truth is...

I'm scared...

(I'm scared.)

See, the emcee is the one who'll whisper the truth. The rapper is the one who'll holla the lies. So don't act surprised at what your daughter knows when she's five Just blame it on the bullsh-t that you buy -look what you've done... 
Overall, Sekou critiques the commercial artificialities of the rapper and champions the authenticity of the spoken word poet (here figured as the "emcee"). The performance of the poem complements its rhetorical structure, which figures the rapper as the consummate Iago. The rapper's criminal boasts are made in character, loudly and publicly, while his truthful admissions are made in confidential asides to his audience (indicated here by the author's use of smaller type) - "I'm broke," "I'm lonely," "I don't have a gun," "I respect women," and finally, "I'm scared." Sekou underscores this duplicity by whispering these asides, and he indicates in italics moments where the dynamics of volume come into play. In the final lines of the poem, Sekou breaks out of character (as indicated in bold face), entering his "authentic" identity as a spoken word poet and asking his audience to justify their consumption of thug rap. Sekou's poem is an example of the critique and re-negotiation of the representation of blackness in mainstream American culture and media, pointing to the political possibilities of commercial projects like Def Poetry. ${ }^{4}$

Still, one must also not ignore the commercial interests of the series - those of Simmons' Def Jam and Phat Farm enterprises, the talent agents involved in the feature of these artists, and HBO. Def Poetry is quickly becoming an important and highly visible part of this franchise: one can now buy DVDs of the HBO series' first few seasons and an anthology of work by performers in the Broadway show, with more products sure to follow. Some of the poets on the series wear Phat Farm fashions (which are given to them gratis), and both Mos Def and Russell Simmons almost always appear in Phat Farm gear.

Even the title of the HBO series reflects commercial branding. Former Executive Producer of Def Poetry Bruce George revealed in an interview that he "wanted to go with 'jam' to keep the branding that Def Comedy Jam had. I wanted to establish a feed off of that branding. And that's one of the reasons why Def Poetry is doing so well, is because of the fact that it's feeding off the branding of Def Comedy Jam, it's feeding off the branding of the record label Def Jam." George compares the mainstream commercialization of poetry to that of rap. Rap music, he posits, in its shift from an art form of unity to that of gangsta-ism, "went from consciousness to consumption." Spoken word, he predicts, will probably experience the same growing pains during its period of "bastardization" into mainstream culture: "Since poetry is moving from the sidestream to the mainstream, there are a lot of people in the music industry that want to jump on the band wagon and follow Russell's lead ... So the big picture is gaining penetration in the record industry ... in VHS and DVD markets ... more national tours, more national competitions, major sponsors like Verizon and AT\&T.... The big picture is it being a lot more commercial" (Interview). Simmons himself confirms this view; in a recent interview, he stated of spoken word poetry: "It's not edgy, fringe or even new. It's very mainstream; all stuff I get involved with is.... I don't think of commercial art in a negative way. I think of commercial art as art that speaks to a lot of people" (Craig).

Yet another example of spoken word's mainstream appeal is Def Poetry Jam on Broadway, the stage show which ran for nearly six months on the Great White Way and which garnered a 2003 Tony Award for Best Special Theatrical Event. ${ }^{5}$ Produced by Russell Simmons and directed by Stan Lathan (who counts the HBO Def 
Poetry series, The Bernie Mac Show, Moesha, Martin, and Cedric "The Entertainer" Presents among his directing credits), the two-hour show features nine spoken word poets of various ethnic backgrounds, including African Americans, Puerto Rican Americans, an Asian American, an Anglo American, and a Jamaican national all from urban areas in the U.S.. Rounding out the cast is an African American DJ who pumps up the audience before and between acts by mixing old-school funk and hip-hop tunes on his turntable.Advertised as "Voices of the Next America" (fig. 1), the cast's racial and ethnic diversity and urban backgrounds are consistently noted by both promoters and theater reviewers. The urban emphasis of the show is reflected by its bare set, composed of seven doorframes painted in grays and beiges suggesting urban stoops and behind which the bare brick wall of the Longacre Theater looms. This street sense is also reflected by the cast's costuming; with the exception of a few of the women, most of the poets take the stage in hip-hop jerseys, tank tops, baseball caps, baggy jeans, tennis shoes, and thrift store finds. ${ }^{6}$

The Broadway show features forty-one poems of about two to five minutes in length. All poems, including the handful of ensemble pieces performed in the production, are original compositions performed by their authors with the exception of one-an Etheridge Knight poem recited by one of the cast members. The entire program is roughly organized by themes of identity and culture, heroes and heroines, love, and reflections on nationality. The final poem, "I Write America," is performed by the entire cast and is an opportunity for the poets to reflect on what America means to them. Both critical and optimistic, they deliver varied visions in this final piece, a diversity they emphasize by talking over each other at the close of the show and creating a verbal dissonance.

Despite Simmons' assertion that the diversity of the Def Poetry Jam Broadway cast was a coincidence, the

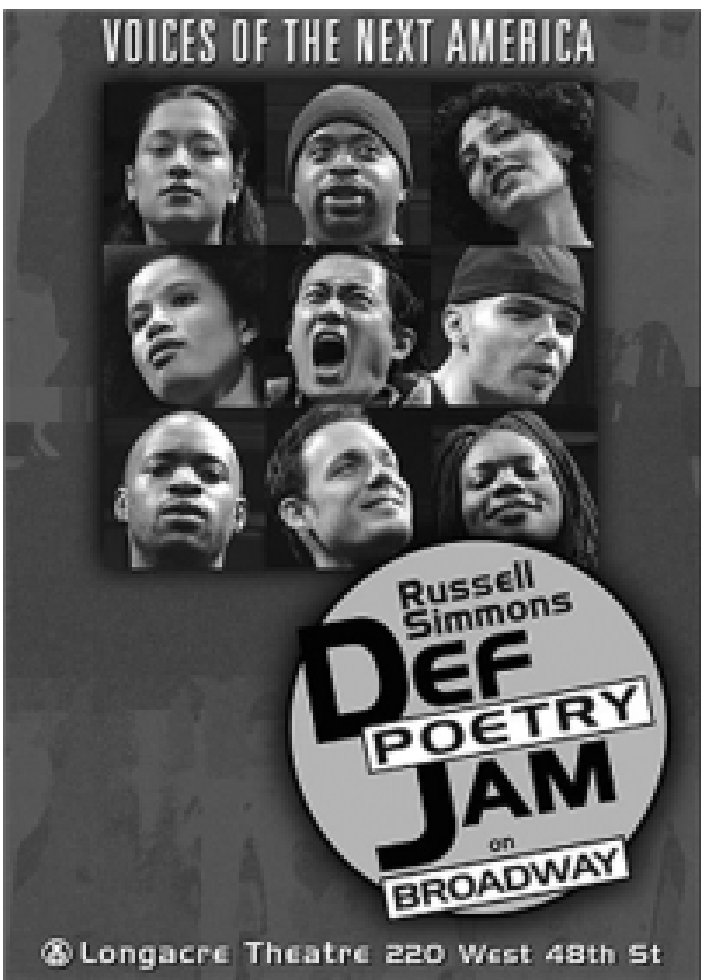

Figure 1. A Def Poetry Jam on Broadway advertisement appearing in The Village Voice online theater section, 2002-3. Pictured clockwise from top left: Mayda del Valle, Poetri, Suheir Hammad, Lemon, Georgia Me, Steve Colman, Black Ice, Staceyann Chin, and Beau Sia (center). 
show's marketing team and his director have played up the urban and multi-cultural identities of the cast. This vision of "The Next America" - the cultural hybridity and difference that can blossom in urban centers such as New York-is perhaps the most prominent theme tying the show together and is the element theater reviewers note the most. Phillip Hopkins writes, "Not only is this incredibly diverse group just as American as the whiter-toned casts more familiar to Broadway audiences, the impression is that they have thought deeply about what the ideas of America means because their own experiences are so often at odds with this country's promises." For other reviewers, this theme rang false. "In general," Martin Denton notes, "none of us would dispute the show's main themes - poverty does beget violence; powerful institutions do ignore the problems of the underprivileged; minority groups are discriminated against in America. But neither would any of us be startled by any of these ideasthere's very little original or interesting thinking in evidence here."

It seems that for better or worse, Def Poetry Jam hopes to promote and capitalize upon the "hipness" of the voices of people of color proclaiming their identities against the status quo. The discourses of marginality abundantly present in the show are discourses that both hip-hop and spoken word poetry share. They also share claims to authenticity, truth, and realness; for example, The San Francisco Chronicle printed a review of the stage show entitled, "Uplifting Hip-Hop Show Really Tells It Like It Is: Well-Versed Poets are Funny and Earthy in 'Def Poetry Jam'" (Sullivan). This patina of authenticity does not exist solely in the opinion of the reviewers; performers and organizers promote Def Poetry Jam as "the real deal." Director Stan Lathan remarks, "There are so many shows I've seen, not just in theater but even more in television, that start out with the hook 'This is telling it like it is.' ... But in the translation from the original concept to the stage or screen it gets diluted. With the poets, my philosophy is, 'Let's put it up there, let's find the best people to perform it and let's get out of their way"' (Pareles). Lathan's comments suggest that this hands-off approach is taken so as to allow the poets to "tell it like it is," or at least tell it like they see it. Cast member Black Ice says with near evangelical fervor that he prefers the non-competitive format of Def Poetry Jam to the openly competitive environment of poetry slams because "my mission in this lifetime is to spread the truth. And when we have a competition of truth, it makes no sense that my truth is truer than yours. Truth can't be conquered, it can only be built upon. And we're dropping truth" (Pareles).

And yet, both Def Poetry Jam's promotional materials and Black Ice's own work directly suggest that the truth of the spoken word poet's experience is precisely in competition with the rapper's. As further proof of this discourse of authenticity, consider this excerpt from the biography of Black Ice (née Lamar Manson) appearing in the Def Poetry Jam on Broadway companion anthology:

The Philadelphia streets grew his potent poetry. Lamar didn't grow up soft.... He was a local shining star, both as a hustler and a fledgling hip-hopper. "I grew up slinging coke and rapping, but finally, I settled down and became a barber and coke dealer. I was still a barber up until a year ago.... When I decided to leave the street game my words and my life began to flourish." 
Broadway was a hard routine for an ex-hustler to crack, but "Ice" never missed a show; a testimony to how much he's turned himself into the messenger of the earth he was destined to be. "Every night I had to re-invent those poems because there is someone out in that audience that needs to hear what I'm about to spit."

... While Black Ice has elevated himself above a street hustler, he did not abandoned [sic] the streets for the lights of Broadway. He's still keeping it real.(119-20)

The biography, presumably written by the anthology's editor, Danny Simmons, reflects many aspects of the commercial rhetoric surrounding black spoken word artists. Most prominently featured are Black Ice's street credentials, conveyed by emphasizing his rough-and-tumble urban youth, his status as a drug-dealer, his skills as a hip-hop MC, and his working-class career as a barber. His "talent and love for art," his narrative argues, was a rehabilitating force saving him from his dangerous criminal lifestyle. Thus, although Black Ice has "elevated himself above a street hustler," the biographical-cum-promotional text assures readers that he still very much retains the authenticity of the street. Here, as we see in many commercial representations of spoken word, the black male spoken word artist is the gangsta reformed through poetic expression.

Black Ice's own poetry attests to this reformation. In his poem "Front Page," for example, Black Ice proclaims his authenticity over the gangsta rapper:

How the fuck you figure your shit is bigger

Than mine

I see you diamond blinking

Cuban Linking and full length minking

All strung out on disillusional thinking

As the government subsidizes

These laboratory high rises

With new chemical surprises

You continue to hide your true self

Behind gangsta' movie disguises

Oblivious to what life's true prize is

Equating stupidity with the length you

Think your dick size is

The truth in your eyes is

Falsify, fabricated while you sit

And wait for your fate to be debated

By juries and judges who've held

Over four hundred and fifty years

Worth of grudges

Nigga get back, sit back and rediscover

How to be an honest father

Loyal lover

Righteous brother

And not just another

Motherfucking nigga.

(from “Front Page," Simmons 102) 
In another poem performed in both the Broadway production and on the $\mathrm{HBO}$ series, "410 Days in the Life," Black Ice explicitly refutes the authenticity of the rapper and, in rejecting that image, makes his own claim to authenticity as a spoken word poet:

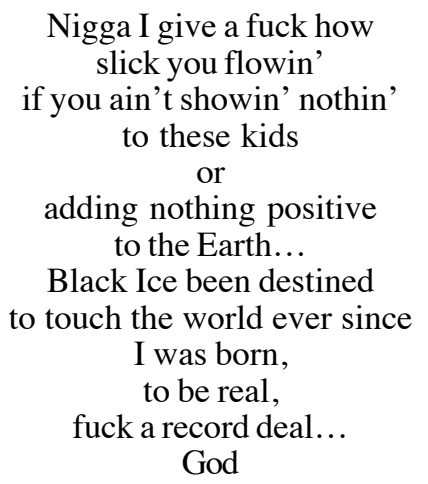

Gives me what I'm worth. (from “410 Days in the Life," Simmons 22)

Important to note here is that Black Ice, like a handful of other spoken word poets appearing in the Def Poetry projects, frequently acknowledges his religious faith. In this respect, his image as a spoken word poet takes on another aspect: he has been spiritually as well as socially reformed through his practice of verse.

Despite such claims of reformation into "realness," audiences and reviewers of the Def Poetry projects have not altogether ignored the artificialities of the projects' commercialism. Denton remarks of the Broadway show:

Thumbing through the program, I see several cast members working steadily on HBO and another with a commercial deal with Nike; I see the wardrobe provided by Barneys, Saks Fifth Avenue, and Bloomingdales; I see support staff that includes an accounting firm, a law firm, an advertising agency, a bank (Chase Manhattan), an insurance company, and a travel agency. These Def Poetry people are the establishment, folks; and no matter how worthy or righteous some of what they have to tell us may be, their integrity [read here: authenticity] strikes me as severely compromised. (Denton)

Since the first whispers about the Def Poetry projects, performance poets have weighed the benefits of reaching a larger mainstream audience with the negative associations conjured by going commercial; but for the majority of these poets, the former outweighs the latter. Broadway cast members Colman and del Valle, for instance, "are happy to see their brand of spoken word performance in its "commercial infancy,' despite the fact that some might consider them sellouts. (The artform [sic] is similar to rap in its early days, they say)" (Katz). Similarly, Simmons makes no apologies for his or his performers' commercial intentions, and he insists that spo- 
ken word poets retain their authenticity even in such venues. "These niggas are honest as the day is long," he states in an interview. "They are commercial as the day is long. They are commercial niggas like me, and there's nothing wrong with that" (Slam Planet).

\section{The Politics of Selling Out: Some Pros and Cons}

The politics of the Def Poetry projects are nuanced and complex as they engage serious issues about race, reception, and representation in mainstream American culture. Just as with black popular musical genres that went mainstream, there are benefits and disadvantages of a poet's entry into the commercial venue of spoken word. The most obvious advantages are the profits and exposure that poets stand to receive by entering the mainstream arena. As a result of the Def Poetry Broadway show and the HBO series, it is more possible than ever for performance poets to make a living by performing and recording their work full-time. Furthermore, the widespread dissemination of spoken word via commercial media presents poets with a unique opportunity to influence a large, mainstream audience. Still, in order to do so, poets must participate in a commercial system which may undermine those messages. This dilemma is similar to the one hip-hop artists faced in the 1990s. As Tricia Rose reminds us:

To refuse to participate in the manipulative process of gaining access to video, recording materials, and performing venues is to almost guarantee a negligible audience and marginal cultural impact. To participate in and try to manipulate the terms of massmediated culture is a double-edged sword that cuts both waysit provides communication channels within and among largely disparate groups and requires compromise that often affirms the very structures much of rap's philosophy seems determined to undermine.(Rose 17)

For spoken word poets, the Def Poetry projects provide a forum for a new generation of empowering black meanings and aesthetics. Still, when spoken word is characterized or perceived as wholly representative of an authentic racial culture, the possibilities of tokenization and fetishization arise.

The commercial and political success of projects like the Def Poetry Jam greatly rely on the tension between dominant and marginalized culture - on the intersections and the competing interests of the two. What makes spoken word poetry such a phenomenon is that it is commercially-oriented yet politically subversive; while it may at times reflect corporate interests it also usually entails spreading a political message. In addition, its language is sometimes homogeneous in style, yet when is it perceived to be so it is parodied and sometimes radically re-invented (as Foxx and Cedric the Entertainer exemplify). Thus, the commercial entity of spoken word poetry is representative of neither mainstream nor marginalized culture, but is dependent on the oscillation between the two. Like rap, it is a genre which "is at once part of the dominant text and, yet, always on the margins of this text; relying on and commenting on the text's center and always aware of its proximity to the border" (Rose 19). 
As the Def Poetry projects clearly privilege black artists and hip-hop aesthetics, what should we make of white poets in the spoken word arena? One reviewer states the case more pointedly of the Broadway show's "lone white performer" who writes exclusively in the rhymed and metered idiom of hip-hop: "Colman seems so blissfully unaware that, in appropriating the hip-hop vernacular and form from its originators, he is as much an exploitative white colonialist as the powerful people that he says he despises" (Denton). In a market where white rappers like Eminem have recently proven commercially successful, many artists and critics are rightly sensitive about this issue. Still, the performances of many white poets who take on black aesthetics seem too nuanced to write off as simply appropriative - if they were merely that, their audiences would run them out on a rail. Instead, these performances seem more a testament to the kind of intercultural and interracial exchange that youth culture has always embraced. Just as the traditionally-black art forms of soul, gospel, and R\&B attracted crossover audiences and led to the social and cultural hybridity of black and white youth, spoken word poetry's crossover into the mainstream may serve as a new site for interracial exchange and possibility. As one critic takes note:

In the past, rap music has been something that has brought young people together, at least around a common style, and may eventually lead to a greater good. Nobody will be particularly convinced that a group of Beverly Hills kids adopting the gangsta lifestyle in terms of talk and dress will be anything but an unwitting parody. Yet, if the kids are looking at the same issues, they may eventually gather some empathy with those who are living the style for real.... And [Def] poetry has simply taken the movement a few steps further. (Craig)

The mass consumption of spoken word as a predominately black art form by white middle-class audiences, however, still raises a much more urgent concern. If black poets are consumed as representing an authentic black experience, or are deemed "hip" simply because of their marginalized statuses, then the commercialization of performance poetry stands to further separate these poets from their mainstream audiences, not bring them together. As in hip-hop, the consumption of spoken word through CDs, DVDs, television and film rather than the reception of spoken word via live performance further troubles the point, because these products obliterate real contact between black artists and white audiences. In this respect, the avid consumption of black spoken word artists by white audiences can become a site of what Samuels calls "racial voyeurism," not racial exchange (29). Thus, although white audiences may feel that, as Henry Louis Gates, Jr. puts it, "by buying records they have made some kind of valid social commitment," they can actually do black artists a disservice (qtd. Samuels 29). It is the unthinking consumer, paired with a potentially uncaring corporate entity, who troubles me here. Poets' discourses of marginality, of the "street," of race and class oppression might very well be the hottest thing because of their difference from the center, from the suburb, from race and class privilege. Because of the ambivalent politics involved in this dynamic and because of the invisibility of these politics to the unthinking con- 
sumer, this fetishistic pattern of consumption can afford marginalized people a mainstream audience while simultaneously marginalizing them further.

In the end, the issue raised by performances of blackness in commercial arenas are not unlike those of over 150 years ago in minstrel venues, although the patronage of spoken word and of blackface minstrelsy have obvious differences. In discussing the commodification of black expression, Eric Lott emphasizes that performances of blackness are performative: they are "a cultural invention, not some precious essence installed in black bodies" (39). The songs, dances, characters, and poetics of blackface performance, he notes, were often created by both black folk and whites together in an odd field work of caricature with the white spectator in mind. Thus, the issue of authenticity is directly implicated in minstrelsy's commodification (60); whites paid to see a blackness that was simultaneously lauded for its authentic representation of slave folk and critiqued for its counterfeit nature as performances of blackness enacted through the burnt cork mask. Lott's articulation of minstrelsy's ambivalent desire for what is authentically black and at the same time counterfeit is, I believe, a valuable contribution toward understanding black performance in general. As in blackface minstrelsy, today's mainstream audiences of spoken word exercise the conflicting and complex dynamics of desire for racial authenticity through their consumption of the genre. Perhaps this is the final appeal of spoken word poetry today - through poets' performances of identity, audiences are given the ultimate power to decide which expressions are authentic and which are counterfeit. In this sense, the desire exercised between poets and audiences in the commercial arena of spoken word is a play for cultural power and meaning, one which will continue to influence and be influenced by the racial landscape of U.S. verse and culture.

\section{Notes}

The author gratefully acknowledges the support of fellowships from the Andrew W. Mellon Foundation and the American Association of University Women which made this research possible.

${ }^{1}$ I refer here to the debate of the late 1980s and early 1990s spawned by Joseph Epstein and made famous by Dana Gioia's essay "Can Poetry Matter?" Both authors argued that poetry had lost touch with a larger intellectual community outside of the academy and needed to seek a public audience in order to continue a poetic tradition. In his latest work, Gioia claims that poetry has recently found a popular audience due to its practice outside of print culture, most notably through audio, video, and the live performance of poetry slams and hip-hop. See Joseph Epstein, "Who Killed Poetry?," Commentary 86.2 (1988): 13-20; Dana Gioia, Can Poetry Matter?: Essays on Poetry and American Culture (Saint Paul, MN: Graywolf P, 1992); Dana Gioia, Disappearing Ink: Poetry at the End of Print Culture (Saint Paul, MN: Graywolf P, 2004).

${ }^{2}$ This is not to say that all African American spoken word artists reflect hip-hop aesthetics - Patricia Smith, DJ Renegade, and Stacyann Chin could be described as reflecting more traditionally "poetic" or jazz aesthetics. Nor is this to say that only black artists can succeed in using the hip-hop idiom - in fact, white artists Danny 
Hoch and Sage Francis and Asian American artist Dennis Kim (a.k.a. Denizen Kane) have achieved a good deal of success as hip-hop spoken word poets. Rather, this discussion is meant to suggest that black spoken word artists who reflect virtuosity in and between hip-hop and poetic idioms - artists such as Saul Williams, Black Ice, or Sekou da Misfit - may have a greater chance of achieving commercial success with white middle-class audiences because of the perceived sense of racebased authenticity surrounding spoken word and hip-hop.

${ }^{3}$ Common examples include replacing the word "nizzle" for "nigger," "scrizzle" for "scrilla" (cash), and "shizzle" for "shit." The first popular use of this idiom is in Frankie Smith's 1981 song "Double Dutch Bus" (Dizzuble Dizzutch), and it has recently been picked up by prominent rappers like Jay-Z and Snoop Dogg. Operating in a culture where there is a premium on "flow" (smooth transition from one lyric to another through improvisational rhyming), today's hip-hop artists no doubt have used this language to increase their capacity for improvisational rhyme. The growing popularity of "izzle" pig Latin also is an inventive way for hip-hop artists to make their songs "clean" for the radio and music videos, and to circumnavigate mandatory parental advisory warnings. In this respect, the use of "izzle" is strategic and profound; rappers have effectively reinvented their language to create a community of listeners in the know and to subvert the recording industry's policies regarding explicit lyrics.

${ }^{4}$ It should be noted that although Sekou's poem contains textual cues as to how he performs it (through the use of bold face, various type sizes and justifications, and italics), such orthography and typography is not the norm in spoken word poetry. In fact, few spoken word poets view their poetry on the page as a script for performance, and most would argue for the consumption of their work in both print and performance. As a hybrid brand of verse, spoken word poetry deserves to be considered within and across these media, even though the relationship between a poem's performance and its appearance on the page can be frustratingly unclear (indeed, sometimes no relationship exists at all). In the absence of consensus on the issue, how a spoken word poem translates from page to stage is best left to a case-by-case analysis.

${ }^{5}$ The show ran from November 14, 2002 to May 5,2003 at Broadway's Longacre Theater. It continues to tour across the U.S. with various cast members.

${ }^{6}$ These observations are drawn from a Def Poetry Jam on Broadway performance that I attended on January 3, 2003.

\section{Works Cited}

Andrews, Sekou. “The Rapper.” Blind Faith Records Website. 2000. 5 Jun 2006. $<$ http://www.blindfaithrecords.com/rapper.html>.

Berfield, Susan. “The CEO of Hip Hop.” Business Week 27 Oct 2003: 90-98. Craig, Pat. “Simmons Keepin' It Real with 'Def Poetry Jam'.” Review of Def Poetry Jam at the Theater on the Square. Contra Costa Times 21 Jun 2002. <http:// www.bayarea.com.mld/cctimes/3517020.htm>.

Denton, Martin. "Def Poetry Jam on Broadway." Review of Def Poetry Jam on Broadway. NYTheatre.com 19 Nov 2002. 4 Feb 2003. <http://www.nytheatre.com/ 
nytheatre/def.htm>.

George, Bruce.Personal Interview. 14 Jul 2002.

The Grammy Awards. Infoplease.com/Pearson Education. 2002. 30 Jan 2003. <http:// www.infoplease.com/ipa/A0150533 html>.

Griffiths, Gareth. "The Myth of Authenticity." The Post-Colonial Studies Reader. Eds. Bill Ashcroft, Gareth Griffiths and Helen Tiffin. New York: Routledge, 1995. 237-41.

Slam Planet: War of the Words. Dirs. Mike Henry and Kyle Fuller. Slam Channel, 2006.

Hopkins, Phillip. “Russell Simmons Def Poetry Jam on Broadway.” Review of Def Poetry Jam on Broadway. TheaterMania.com. 15 Nov 2002. 12 Jan 2003.<http:// www.theatermania.com/news/reviews/index.cfm?story $=2789 \& \mathrm{cid}=1>$.

Jefferson,Elana Ashanti. "Def Jam Poetry Hip-Hops into Denver's Spotlight." Denver Post Online Edition, Entertainment Section. 16 Jan 2005. 24 Jan 2005. $<$ http://www.denverpost.com/Stories/0\%2C1413\%2C36 78 2652088\%2C00.html .

Katz,Leslie. "Universal Language of Poetry." Review of Def Poetry Jam at the Theater on the Square. The San Francisco Examiner 17 Jul 2002. 4 Feb 2003. $<\mathrm{http} / /$ www.examiner.com/ex_files/default.jsp?story=X0719DEFw>.

Russell Simmons Presents Def Poetry (Episode 3, Season 1). Dir. Stan Lathan. Perf. Cedric the Entertainer, Willie Perdomo, Beau Sia, and The Last Poets. 2002. DVD. Home Box Office, 2004.

Lott, Eric. Love and Theft: Blackface Minstrelsy and the American Working Class. New York: Oxford UP, 1993.

Pareles, Jon. “A New Platform for the New Poets.” The New York Times 10 Nov 2002, late ed.: sec. 2:1.

Quickley, Jerry. "Hip Hop Poetry.” Spoken Word Revolution: Slam, Hip Hop, and the Poetry of a New Generation.Ed. Mark Eleveld. Naperville, IL: Sourcebooks MediaFusion, 2003.38-42.

Rose, Tricia. Black Noise: Rap Music and Black Culture in Contemporary America. Middletown, CT: Wesleyan UP, 1994.

Samuels, David. “The Rap on Rap: The 'Black Music'That Isn't Either.” The New Republic 11 Nov. 1991:24-29.

Simmons, Danny, ed. Russell Simmons Def Poetry Jam on Broadway ... and More: The Choice Collection. New York: Atria Books, 2003.

Sullivan, James. "Uplifting Hip-Hop Show Really Tells It Like It Is: Well-Versed Poets are Funny and Earthy in 'Def Poetry Jam'." Review of Def Poetry Jam at the Theater on the Square. San Francisco Chronicle 27 Jun 2002: D1.

Watkins, S. Craig. Representing: Hip Hop Culture and the Production of Black Cinema. Chicago: U of Chicago P, 1998.

"Who's Who in the Cast: Def Poetry Jam." Playbill Theater Edition Jan 2003: Insert. 